\title{
Inhibitory effects of low-intensity pulsed ultrasound sonication on the proliferation of osteosarcoma cells
}

\author{
TOSHIHIRO MATSUO $^{1}$, KEIJI SATO ${ }^{1}$, TAKUYA MATSUI ${ }^{2}$, SHIGEYUKI SAWADA $^{1}$, YOSHITAKA MURAMATSU $^{1}$, \\ KATSUHISA KAWANAMI $^{1}$ and MASATAKA DEIE ${ }^{1}$
}

Departments of ${ }^{1}$ Orthopaedic Surgery and ${ }^{2}$ Physiology, Aichi Medical University, Nagakute, Aichi 480-1195, Japan

Received February 9, 2017; Accepted May 16, 2017

DOI: $10.3892 / \mathrm{ol} .2017 .6472$

\begin{abstract}
To date, there is limited data on the biological effects of low-intensity pulsed ultrasound (LIPUS) on primary malignant bone tumors. The purpose of the present study was to investigate the antitumor effects of LIPUS on osteosarcoma cells. The effects of LIPUS on cell viability, induction of apoptosis, mitochondrial membrane potential and intracellular signaling molecules in the LM8 osteosarcoma cell line were investigated. LIPUS inhibited cell viability $(\mathrm{P}=0.0022)$ and mitochondrial membrane potential $(\mathrm{P}=0.0019)$ in LM8 cells. Flow cytometry analysis and terminal deoxynucleotidyl transferase dUTP nick end labeling staining revealed significantly higher numbers of apoptotic $(\mathrm{P}<0.0001)$ and necrotic cells $(\mathrm{P}=0.0091)$ compared with cells without treatment. LIPUS treatment significantly increased phosphorylated Akt $(\mathrm{P}<0.0001)$ and $\mathrm{I} \kappa \mathrm{B} \alpha(\mathrm{P}=0.0001)$ levels, and reduced phosphorylated mitogen-activated protein kinase $7(\mathrm{P}<0.0001)$ and phosphorylated checkpoint kinase $1(\mathrm{P}=0.0008)$ levels. These results suggest that LIPUS is a non-invasive adjuvant therapy that is able to inhibit cellular proliferation in osteosarcoma cells.
\end{abstract}

\section{Introduction}

Osteosarcoma, which arises from mesenchymal osteoblasts, is the most common malignant bone cancer in children and adolescents (1). Despite the effective use of chemotherapy (2) and surgical techniques (3) in controlling osteosarcoma, there remains a mortality of rate of $\sim 30 \%$. In addition, patients with unresectable primary tumors or clinically evident metastases have a poor prognosis, even in chemotherapy-responsive cases of osteosarcoma $(4,5)$. Therefore, novel effective therapeutic approaches for the treatment of osteosarcoma are required.

Correspondence to: Dr Toshihiro Matsuo, Department of Orthopaedic Surgery, Aichi Medical University, 1-1 Yazakokarimata, Nagakute, Aichi 480-1195, Japan

E-mail: matsuot@aichi-med-u.ac.jp

Key words: low-intensity pulsed ultrasound, osteosarcoma, LM8, sonication, apoptosis
Low-intensity pulsed ultrasound (LIPUS) is a non-invasive ultrasound medical technology that uses low-frequency, low-intensity pulses. LIPUS was previously demonstrated to promote bone formation and accelerate bone maturation in cases of bone fracture $(6,7)$, distraction osteogenesis (8) and delayed fracture union (9). LIPUS appears to act by affecting the biological mechanisms of cell proliferation, gene regulation and cell differentiation (10). Osteosarcoma is characterized by the production of malignant osteoid matrix and differentiation of mesenchymal osteoblasts (11). LIPUS affects osteoblastic differentiation without increasing the number of osteoblasts $(12,13)$. Therefore, the authors hypothesize that LIPUS inhibits osteoblastic differentiation by inducing apoptosis and inhibiting cell growth in osteosarcoma cells. To examine the proposed antitumor effects of LIPUS, cells from the LM8 osteosarcoma cell line were treated with LIPUS, and the effects on cell growth, apoptosis, mitochondrial membrane potential and intracellular signaling molecules were investigated.

\section{Materials and methods}

Cells and culture. LM8 mouse osteosarcoma and MC3T3-E1 mouse osteoblastic cells were obtained from the Japanese Collection of Research Bioresources Cell Bank (Ibaraki, Japan) and were maintained in Eagle's minimal essential medium (Sigma-Aldrich; Merck KGaA, Darmstadt, Germany) containing $10 \%$ heat-inactivated fetal calf serum, $100 \mathrm{U} / \mathrm{ml}$ penicillin and $100 \mathrm{mg} / \mathrm{ml}$ streptomycin (all from Gibco; Thermo Fisher Scientific, Inc., Waltham, MA, USA) at $37^{\circ} \mathrm{C}$ in a humidified incubator containing $5 \% \mathrm{CO}_{2}$.

Ultrasound apparatus and treatment. The Sonic Accelerated Fracture Healing System ultrasound apparatus (Teijin Ltd., Osaka, Japan) was used with $1.5 \mathrm{MHz}$ frequency pulses, with a pulse width of $200 \mu \mathrm{s}$, repeated at $1 \mathrm{kHz}$, at a spatial average and temporal average intensity of $30 \mathrm{~mW} / \mathrm{cm}$, in all sonication experiments. The LIPUS transducer was placed horizontally on each plate of cells for different times (1, 12, 18 or $24 \mathrm{~h})$. In control experiments, the cells were treated in the same manner without LIPUS exposure.

Cell proliferation assay. LM8 cells were seeded into 96-well black/clear plates (Falcon; Corning Incorporated, Corning, NY, USA) at a density of $1 \times 10^{4}$ cells/well. MC3T3-E1 cells 
were seeded into black/clear 96-well plates at a density of $7.5 \times 10^{3}$ cells/well. Following incubation overnight at $37^{\circ} \mathrm{C}$, the cells were treated with or without LIPUS for $1,12,18$ or $24 \mathrm{~h}$. The WST-8 reagent (Cell Counting Kit-8; Dojindo Molecular Technologies, Inc., Kumamoto, Japan) The WST-8 reagent (Cell Counting Kit; Dojindo Lab, Tokyo, Japan) was added to each well, and the cells were cultured for $2 \mathrm{~h}$ according to the manufacturer's protocol. Absorbance in conditioned medium (Eagle's minimal essential medium: Sigma-Aldrich; Merck $\mathrm{KGaA}$ ) was monitored at $490 \mathrm{~nm}$ using a microplate reader (Molecular Devices LLC, Sunnyvale, CA, USA). IC $_{50}$ values were calculated using the Softmax Pro software 6 (Molecular Devices LLC).

Measurement of mitochondrial membrane potential. LM8 cells were seeded into 96 -well black/clear plates at a density of $4 \times 10^{4}$ cells/well. MC3T3-E1 cells were seeded into black/clear 96-well plates at a density of $2 \times 10^{4}$ cells/well. Following incubation overnight at $37^{\circ} \mathrm{C}$, the cells were treated with or without LIPUS for $48 \mathrm{~h}$. The mitochondrial membrane potential of the cells were measured using a membrane potential cytotoxicity kit (Mito-ID; Enzo Life Sciences, Inc., Farmingdale, NY, USA) and fluorescence microscopy (IX73; Olympus Corporation, Tokyo, Japan).

Apoptosisassayandflow cytometry.LM8 cells ( $1 \times 10^{6}$ cells/well) were cultured in a 35-mm dish (Lumox dish 35; Sarstedt K.K., Tokyo, Japan) and stimulated with LIPUS at $37^{\circ} \mathrm{C}$ for $48 \mathrm{~h}$. The LM8 cells were then treated with trypsin-EDTA, washed with PBS and resuspended in binding buffer (Medical \& Biological Laboratories Co., Ltd., Nagoya, Japan) according to the manufacturer's protocol. Cell suspension $(85 \mu \mathrm{l})$ was then incubated with $10 \mu \mathrm{l}$ Annexin V/fluorescein isothiocyanate and $5 \mu \mathrm{l}$ protein iodide. After a 15 -min incubation at room temperature in the dark, $400 \mu 1$ binding buffer was added. The cells were analyzed by flow cytometry (FACSCanto II; BD Biosciences, San Jose, CA, USA) and the results were analyzed using software (FlowJo version 10.2; Tomy Digital Biology, Tokyo, Japan).

Terminal deoxynucleotidyl transferase dUTP nick end labelling (TUNEL) assay. An Apoptosis In Situ Detection kit (Wako Pure Chemical Industries, Ltd., Osaka, Japan) was used to measure apoptosis using the TUNEL staining method, according to the manufacturer's protocol, following treatment of LM8 $\left(1 \times 10^{6}\right)$ cells with LIPUS at $37^{\circ} \mathrm{C}$ for $48 \mathrm{~h}$. TUNEL-positive and TUNEL-negative cells were counted in four random high-power fields (magnification, x400) of each section. The rate of apoptosis was calculated using the following equation: TUNEL-positive cell number/total cell number x100 (\%).

Screening intracellular apoptosis signaling. LM8 cells were seeded into a 35-mm dish (Lumox dish 35) at a density of $1 \times 10^{6}$ cells. Following incubation overnight at $37^{\circ} \mathrm{C}$, the cells were exposed to LIPUS for 24 or $48 \mathrm{~h}$. The cells were then treated with trypsin-EDTA, rinsed with cold PBS and solubilized in cell lysate buffer (Cell Signaling Technology, Inc. Danvers, MA, USA) containing a complete inhibitor cocktail (Roche Diagnostics GmbH, Mannheim, Germany) and $1 \mathrm{mM}$
PMSF (phenylmethyl sulfonyl fluoride; Sigma-Aldrich; Merck $\mathrm{KGaA}$ ) buffer. Lysates were subsequently rocked gently at $4^{\circ} \mathrm{C}$ for $30 \mathrm{~min}$. Following centrifugation at $14,000 \mathrm{x}$ g for $5 \mathrm{~min}$ at $4^{\circ} \mathrm{C}$, the supernatants were transferred to test tubes. Sample protein levels were quantified using Bradford method (Protein Assay; Bio-Rad Laboratories, Inc., Hercules, CA, USA) and then diluted to a concentration of $1.0 \mathrm{mg} / \mathrm{ml}$ and used with the PathScan Stress and Apoptosis Signaling Antibody Array kit (Cell Signaling Technology, Inc.) according to the manufacturer's protocol. The detected dots were visualized using the supplied LumiGLO reagent and enumerated with the ImageQuant LAS-4000 instrument (GE Healthcare, Chicago, IL, USA). The relative dot densities were determined with ImageJ version 1.48 software (National Institutes of Health, Bethesda, MD, USA), normalized to the relative density of $\alpha$-tubulin.

Statistical analysis. The significance of differences between groups was evaluated by a paired t-test. Data are presented as the mean \pm standard deviation of 6-10 replications performed. In all analyses, $\mathrm{P}<0.05$ was considered to represent a statistically significant difference. All analyses were performed using the Statview statistical software package (version 5.0; Abacus Concepts, Berkley, CA, USA).

\section{Results}

Inhibition of cell viability. Treatment with LIPUS for 18 or 24 h significantly inhibited the growth of LM8 cells, compared with no treatment ( $18 \mathrm{~h}, \mathrm{P}=0.0133 ; 24 \mathrm{~h}, \mathrm{P}=0.0022)$. There was no significant difference in cell growth when treated for 1 or $12 \mathrm{~h}$ compared with no treatment $(1 \mathrm{~h}, \mathrm{P}=0.3762 ; 12 \mathrm{~h}$, $\mathrm{P}=0.1858$; Fig. 1). Treatment with LIPUS for 1 or $12 \mathrm{~h}$ significantly inhibited the growth of MC3T3-E1 cells, compared with no treatment $(1 \mathrm{~h}, \mathrm{P}=0.0048 ; 12 \mathrm{~h}, \mathrm{P}<0.0001)$. There was no significant difference in cell growth when treated for 18 or $24 \mathrm{~h}$ compared with no treatment $(18 \mathrm{~h}, \mathrm{P}=0.6574 ; 24 \mathrm{~h}$, $\mathrm{P}=0.3606$; Fig. 2).

Effects on mitochondrial membrane potential. LM8 cells treated with LIPUS for $48 \mathrm{~h}$ had a significantly lower mitochondrial membrane potential compared with cells without treatment $(\mathrm{P}=0.0019)$, but there were no significant differences in mitochondrial membrane potential between MC3T3-E1 cells with or without LIPUS treatment $(\mathrm{P}=0.2437$; Fig. 3).

Induction of apoptosis. Flow cytometry analysis revealed that the LM8 cells treated with LIPUS had significantly higher numbers of apoptotic and necrotic cells compared with cells without treatment (apoptotic cells, $\mathrm{P}<0.0001$; necrotic cells, $\mathrm{P}=0.0091$; Figs. 4 and 5). TUNEL staining analysis indicated that the LM8 cells treated with LIPUS had significantly higher numbers of apoptotic cells compared with cells without LIPUS treatment $(\mathrm{P}<0.0001$; Figs. 6 and 7$)$.

Analysis of intracellular signaling molecules. As determined with a stress and apoptosis signaling array (Fig. 8), LIPUS treatment of LM8 cells for $24 \mathrm{~h}$ significantly enhanced the levels of phosphorylated (p)-mitogen-activated protein kinase 3/1 (ERK1/2), p-Akt and NF- $\kappa$ B inhibitor $\alpha(\mathrm{I} \kappa \mathrm{B} \alpha$; 


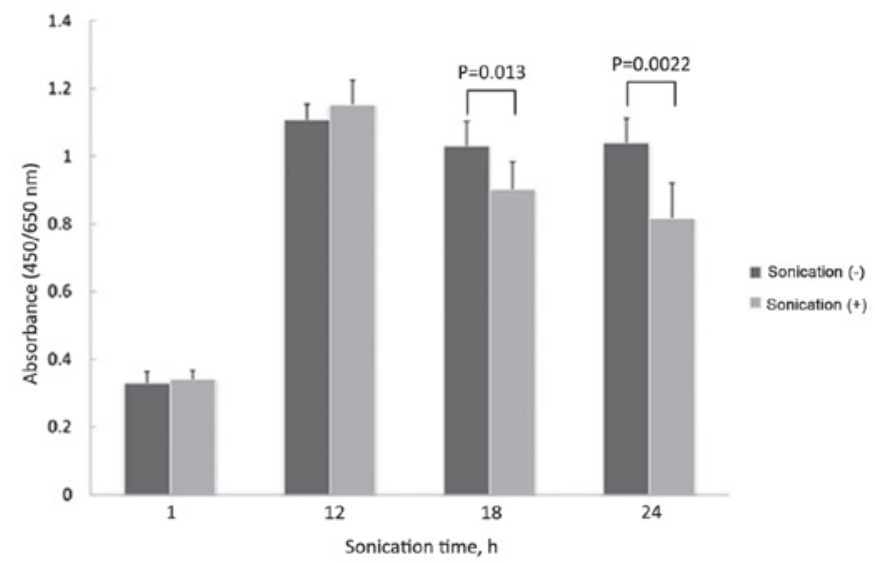

Figure 1. Viability of LM8 cells treated with LIPUS. Treatment with LIPUS for 18 or $24 \mathrm{~h}$ significantly inhibited the growth of LM8 cells ( $18 \mathrm{~h}, \mathrm{P}=0.0133$; $24 \mathrm{~h}, \mathrm{P}=0.0022$ ), compared with no treatment. No significant differences in cell growth between cells treated with LIPUS for 1 or $12 \mathrm{~h}$ and untreated cells ( 1 h, $\mathrm{P}=0.3762 ; 12$ h, $\mathrm{P}=0.1858$ ). LIPUS, low-intensity pulsed ultrasound.

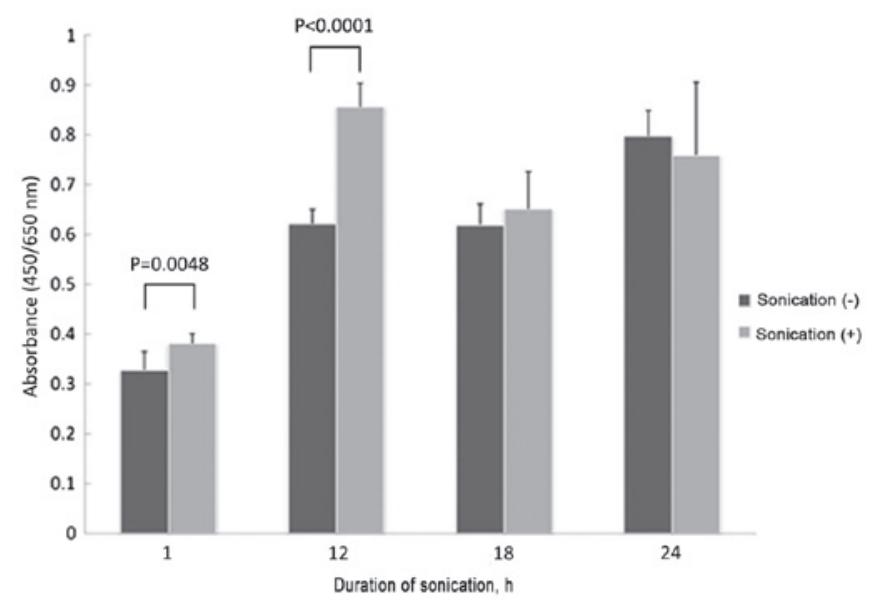

Figure 2. Viability of MC3T3-E1 cells treated with LIPUS. Treatment with LIPUS for 1 or $12 \mathrm{~h}$ significantly inhibited the growth of MC3T3-E1 cells ( $1 \mathrm{~h}, \mathrm{P}=0.0048$ and $12 \mathrm{~h}, \mathrm{P}<0.0001$ ), compared with no treatment. No significant difference in cell growth between cells treated with LIPUS for 18 or $24 \mathrm{~h}$ compared with untreated cells ( $18 \mathrm{~h}, \mathrm{P}=0.6574 ; 24 \mathrm{~h}, \mathrm{P}=0.3606)$. LIPUS, low-intensity pulsed ultrasound.

p-ERK1/2 P<0.0001; p-Akt; $\mathrm{P}<0.0001 ;$ IкB $\alpha: \mathrm{P}<0.0001)$ and reduced the levels of $\mathrm{p}$-mitogen-activated protein kinase 7 (TAK1) and p-checkpoint kinase 1 (Chk1; TAK1, $\mathrm{P}<0.0001$; Chk1, $\mathrm{P}=0.0006)$. However, there were no effects on the levels of p-Bcl-2-associated agonist of cell death (Bad) ( $\mathrm{P}=0.6926$; Fig. 9). LIPUS treatment of the LM8 cells for $48 \mathrm{~h}$ significantly increased p-Akt and IкB $\alpha$ levels (Akt, $\mathrm{P}<0.0001$; $\mathrm{I} \kappa \mathrm{B} \alpha, \mathrm{P}=0.0001)$ and reduced $\mathrm{p}-\mathrm{TAK} 1$ and $\mathrm{p}-\mathrm{Chk} 1$ levels (p-TAK1, $\mathrm{P}<0.0001$; $\mathrm{p}-\mathrm{Chk1}, \mathrm{P}=0.0008$ ). However, there were no effects on the levels of p-ERK1/2 or p-Bad (p-ERK1/2, $\mathrm{P}=0.2437$; Bad, $\mathrm{P}=0.9837$; Fig. 10).

\section{Discussion}

LIPUS therapy may promote bone formation in cases of fracture $(6,7)$ and accelerate bone maturation in cases of distraction osteogenesis (8) and delayed fracture union (9) by positively

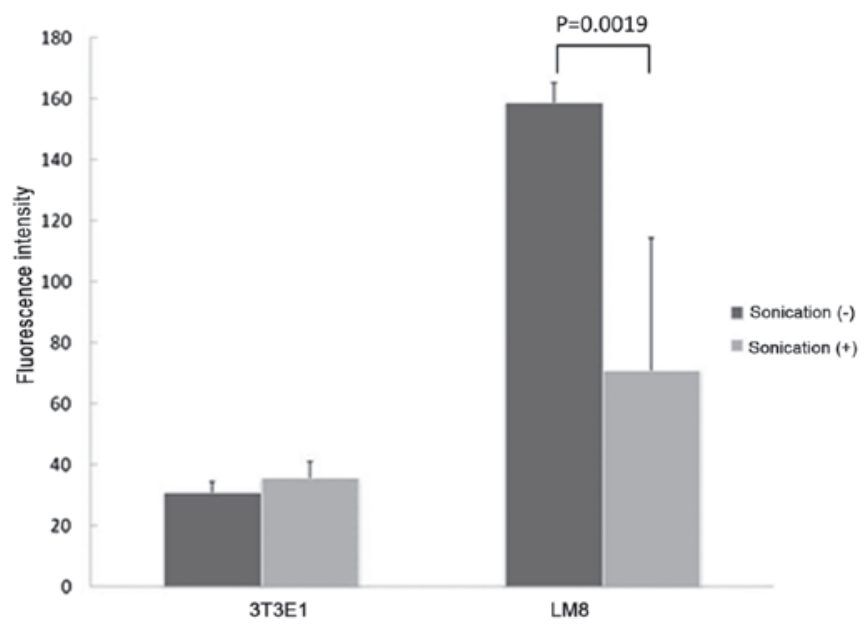

Figure 3. Effects on mitochondrial membrane potential of $48 \mathrm{~h}$ LIPUS treatment. LM8 cells subjected to LIPUS treatment for $48 \mathrm{~h}$ had a significantly lower mitochondrial membrane potential compared with untreated cells $(\mathrm{P}=0.0019)$. No significant differences between MC3T3-E1 cells with and without LIPUS treatment $(\mathrm{P}=0.2437)$. LIPUS, low-intensity pulsed ultrasound.
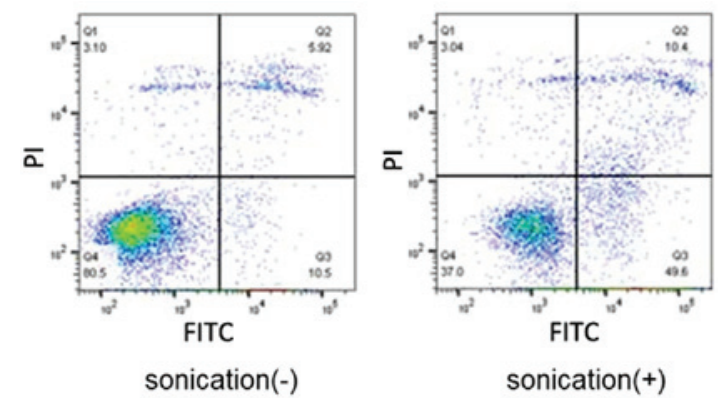

Figure 4. Representative image of flow cytometry detection of apoptosis and necrosis in LM8 cells treated with low-intensity pulsed ultrasound for $48 \mathrm{~h}$. PI, propidium iodide; FITC, fluorescein isothiocyanate.

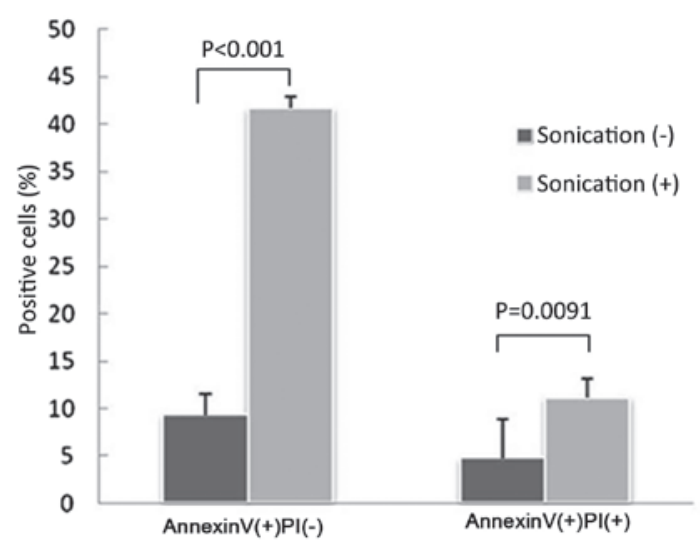

Figure 5. Quantification of flow cytometry detection of apoptosis and necrosis in LM8 cells treated with LIPUS for $48 \mathrm{~h}$. Flow cytometry analysis indicated that LM8 cells treated with LIPUS had significantly higher numbers of apoptotic and necrotic cells compared with untreated cells (apoptotic cells, $\mathrm{P}<0.0001$; necrotic cells, $\mathrm{P}=0.0091$ ). LIPUS, low-intensity pulsed ultrasound; PI, propidium iodide

affecting all phases of fracture repair (14), as well as eliciting effects on cyclooxygenase $2(15,16)$ and prostaglandins $(17,18)$. 


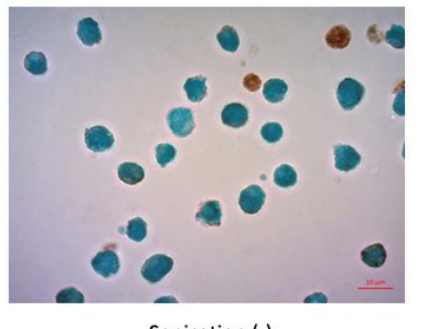

Sonication (-)

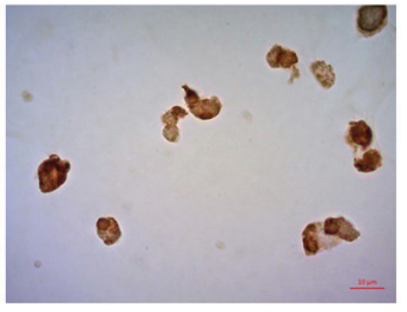

Sonication (+)
Figure 6. Representative image of terminal deoxynucleotidyl transferase dUTP nick end labeling staining of LM8 cells, with or without low-intensity pulsed ultrasound treatment.

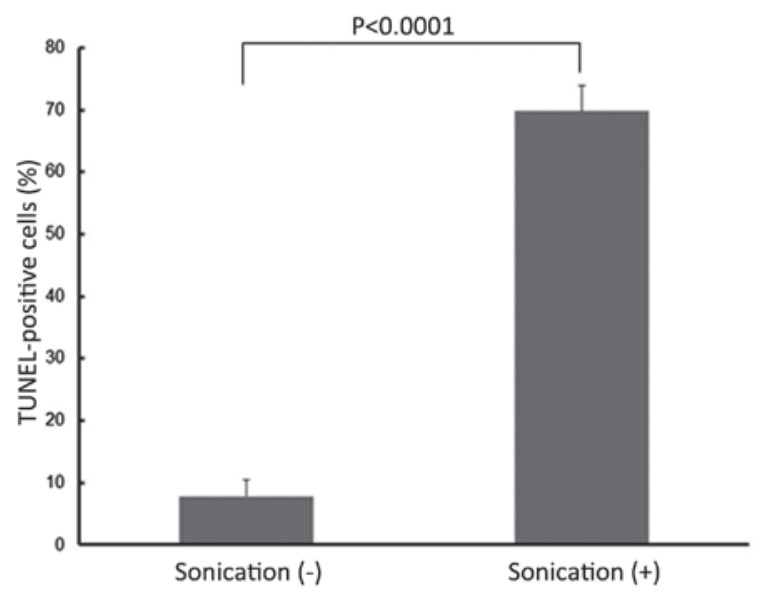

Figure 7. Rate of TUNEL-positive cells. TUNEL staining revealed that LM8 cells treated with LIPUS had significantly higher numbers of apoptotic cells compared with untreated cells $(\mathrm{P}<0.0001)$. TUNEL, terminal deoxynucleotidyl transferase dUTP nick end labeling; LIPUS, low-intensity pulsed ultrasound.

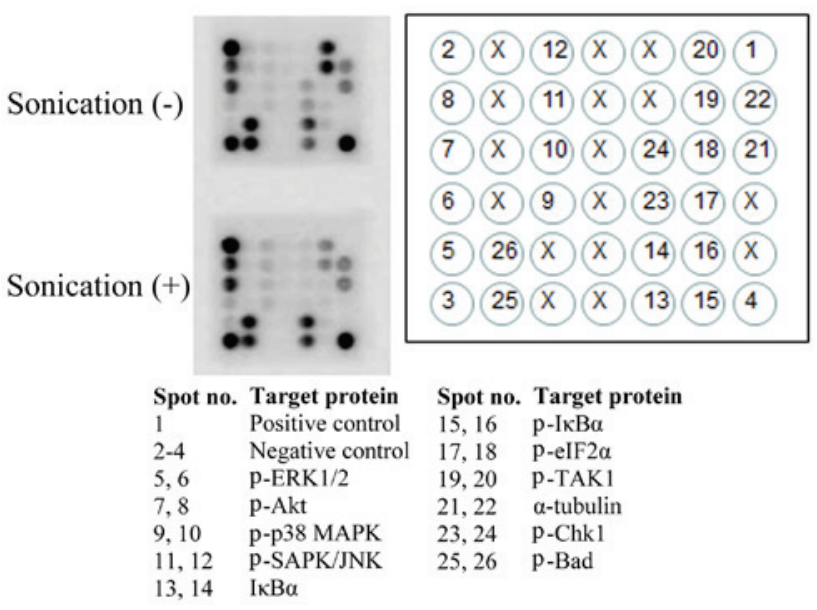

Figure 8. Representative image of a stress and apoptosis signaling protein array following the treatment of LM8 cells with or without low-intensity pulsed ultrasound for $48 \mathrm{~h}$. X, blank spot; p-, phosphorylated; ERK, mitogen-activated protein kinase; MAPK, mitogen-activated protein kinase;

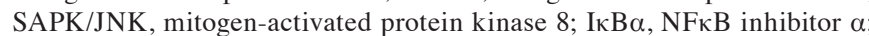
eIF2 $\alpha$, eukaryotic translation initiation factor $2 \alpha$; TAK1, mitogen-activated protein kinase 7; Chk1, checkpoint kinase 1; Bad, Bcl-2-associated agonist of cell death.

There have been several studies reporting that LIPUS has antitumor effects via the induction of apoptosis in cancer

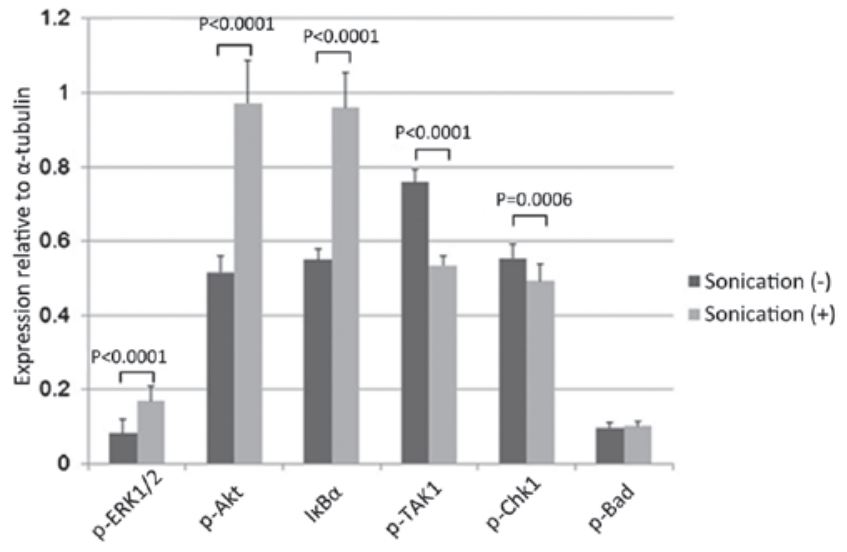

Figure 9. Effects on comprehensive intracellular signaling following LIPUS treatment for $24 \mathrm{~h}$. LM8 cells were treated with LIPUS for $24 \mathrm{~h}$, resulting in a significant increase in p-ERK1/2, p-Akt, and IкB $\alpha$ levels (p-ERK1/2, $\mathrm{P}<0.0001$; p-Akt, $\mathrm{P}<0.0001 ; \mathrm{I} \kappa \mathrm{B} \alpha, \mathrm{P}<0.0001)$ and a decrease in $\mathrm{p}-\mathrm{TAK} 1$ and $\mathrm{p}$-Chk1 levels ( $\mathrm{p}$-TAK1, $\mathrm{P}<0.0001 ; \mathrm{p}$-Chk1, $\mathrm{P}=0.0006$ ). There was no effect on $\mathrm{p}$-Bad levels $(\mathrm{P}=0.6926)$. LIPUS, low-intensity pulsed ultrasound; ERK1/2, mitogen-activated protein kinase 3/1; IкB $\alpha, \mathrm{NF \kappa B}$ inhibitor $\alpha$; TAK1, mitogen-activated protein kinase 7; Chk1, checkpoint kinase 1; Bad, Bcl-2-associated agonist of cell death.

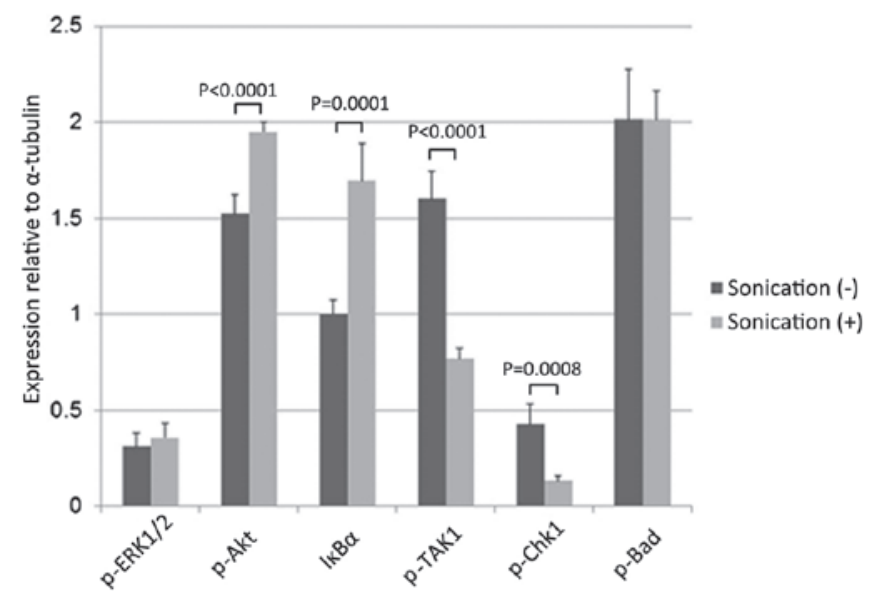

Figure 10. Effects on intracellular signaling following LIPUS treatment for $48 \mathrm{~h}$. LM8 cells were treated with LIPUS for $48 \mathrm{~h}$, resulting in a significant increase in p-Akt and I $\mathrm{B} \alpha$ levels (p-Akt, $\mathrm{P}<0.0001$; I $\mathrm{B} \alpha, \mathrm{P}=0.0001$ ) and a decrease in $\mathrm{p}-\mathrm{TAK} 1$ and $\mathrm{p}-\mathrm{Chk} 1$ levels (p-TAK1, $\mathrm{P}<0.0001$; $\mathrm{p}-\mathrm{Chk} 1$, $\mathrm{P}=0.0008)$. There were no effects on $\mathrm{p}$-ERK $1 / 2$ or $\mathrm{p}$-Bad levels (p-ERK1/2, $\mathrm{P}=0.2437$; $\mathrm{Bad}, \mathrm{P}=0.9837$ ). LIPUS, low-intensity pulsed ultrasound; IкB $\alpha$, NFkB inhibitor $\alpha$; TAK1, mitogen-activated protein kinase 7; Chk1, checkpoint kinase 1; ERK, mitogen-activated protein kinase; Bad, Bcl-2-associated agonist of cell death.

cells (19-23). For example, LIPUS was previously demonstrated to induce apoptosis by causing membrane damage in human leukemia cells (19), affecting the $\mathrm{Ca}^{2+} /$ mitochondrial pathway in human hepatocellular carcinoma cells (23) and enhancing adjuvant chemotherapy in cases of lymphoma (20). However, there is currently limited data regarding the antitumor effects of LIPUS on osteosarcoma cells, although the treatment of osteosarcoma in children and adolescents remains a serious challenge.

In previous studies, the mechanical stress caused by LIPUS stimulation of osteoblasts was demonstrated to induce the expression of chemokines and the receptors of nuclear factor $\kappa \mathrm{B}$ ligand, 
an essential osteoblast differentiation factor (12). Furthermore, LIPUS stimulates the ability of osteoblasts to differentiate, mature and form bone, with elevated bone sialoprotein expression observed during late osteoblast differentiation (13). As osteosarcoma is characterized by malignant osteoblastic differentiation and osteoid matrix production (11), cell growth was investigated in the present study to determine whether LIPUS may be used to inhibit osteosarcoma cell growth. The results revealed that treatment with LIPUS for 18 or $24 \mathrm{~h}(\mathrm{P}=0.0133$ and $\mathrm{P}=0.0022$, respectively) significantly inhibited LM8 cell growth, whereas no effects were observed on MC3T3-E1 cell growth at the same time points. Additionally, the LM8 cells undergoing LIPUS treatment for $48 \mathrm{~h}$ exhibited a significantly lower mitochondrial membrane potential compared with untreated cells $(\mathrm{P}=0.0019)$, whereas no significant effects were observed in the MC3T3-E1 cells, with or without treatment. These results indicate that mechanical stimulation of osteosarcoma cells by LIPUS damages intracellular mitochondria, decreases mitochondrial membrane potential and inhibits viability. In addition, flow cytometry analysis revealed that LM8 cells subjected to LIPUS treatment had significantly higher numbers of apoptotic and necrotic cells compared with untreated cells (apoptotic cells, $\mathrm{P}<0.0001$; necrotic cells, $\mathrm{P}=0.0091$ ), and TUNEL staining analysis demonstrated that LM8 cells treated with LIPUS had significantly higher numbers of apoptotic cells compared with cells without treatment $(\mathrm{P}<0.0001)$. These results demonstrate that LIPUS treatment effectively inhibits cell viability and induces apoptosis in osteosarcoma cells.

Previous reports have revealed that LIPUS stimulated the phosphorylation of ERK1/2 and Akt in osteosarcoma cell lines (21) as well as the activation of ERK1/2 in osteosarcoma cells, which have been induced to undergo apoptosis and autophagy (24). In addition, Akt may induce apoptosis via inhibition of Chk1 (25). In the present study, the levels of p-ERK1/2 and $\mathrm{p}$-Akt were increased and the level of $\mathrm{p}$-Chk1 was decreased in apoptotic LM8 cells following LIPUS treatment.

TAK1, a common upstream regulator of NF- $\kappa \mathrm{B}$, prevents apoptosis via NF- $\kappa \mathrm{B}$-induced downregulation of $\mathrm{I} \kappa \mathrm{B} \alpha(26,27)$. This mechanism may partially explain why LIPUS treatment significantly reduced the levels of p-TAK1 $(\mathrm{P}<0.0001)$ and enhanced the levels of $\mathrm{I} \kappa \mathrm{B} \alpha(\mathrm{P}=0.0001)$ as a result of the induction of apoptosis in LM8 cells.

The use of adjuvant chemotherapy has proven effective in osteosarcoma $(2,4)$. Despite treatment advances and significant improvements in survival rate, the prognosis for patients with osteosarcoma remains poor (4). To improve the prognosis of patients with osteosarcoma, it is necessary to develop novel effective adjuvant treatments. LIPUS, in combination with chemotherapy or radiation, is a promising therapy for osteosarcoma patients.

In conclusion, it has been demonstrated that LIPUS treatment may effectively inhibits cell growth and induces apoptosis in osteosarcoma cells. As a non-invasive approach, LIPUS promises a range of clinical advantages, including brief, targeted applications to the tumor site.

\section{Acknowledgements}

The authors wish to express sincere appreciation for technical assistance to Mrs Mayu Takagi from WDB Co.

\section{References}

1. Broadhead ML, Clark JC, Myers DE, Dass CR and Choong PF: The molecular pathogenesis of osteosarcoma: A review. Sarcoma 2011: 959248, 2011.

2. Rosen G, Marcove RC, Caparros B, Nirenberg A, Kosloff C and Huvos AG: Primary osteogenic sarcoma: The rationale for preoperative chemotherapy and delayed surgery. Cancer 43: 2163-2177, 1979

3. Enneking WF and Dunham WK: Resection and reconstruction for primary neoplasms involving the innominate bone. J Bone Joint Surg Am 60: 731-746, 1978.

4. Ham SJ, Schraffordt Koops H, van der Graaf WT, van Horn JR, Postma L and Hoekstra HJ: Historical, current and future aspects of osteosarcoma treatment. Eur J Surg Oncol 24: 584-600, 1998.

5. Durfee RA, Mohammed M and Luu HH: Review of osteosarcoma and current management. Rheumatol Ther 3: 221-243, 2016.

6. Heckman JD, Ryaby JP, McCabe J, Frey JJ and Kilcoyne RF: Acceleration of tibial fracture-healing by non-invasive, low-intensity pulsed ultrasound. J Bone Joint Surg Am 76: 26-34, 1994.

7. Harrison A, Lin S, Pounder N and Mikuni-Takagaki Y: Mode and mechanism of low intensity pulsed ultrasound (LIPUS) in fracture repair. Ultrasonics 70: 45-52, 2016.

8. El-Mowafi $\mathrm{H}$ and Mohsen M: The effect of low-intensity pulsed ultrasound on callus maturation in tibial distraction osteogenesis. Int Orthop 29: 121-124, 2005.

9. Rutten S, Nolte PA, Guit GL, Bouman DE and Albers GH: Use of low-intensity pulsed ultrasound for posttraumatic nonunions of the tibia: A review of patients treated in the Netherlands. J Trauma 62: 902-908, 2007.

10. Xin Z, Lin G, Lei H, Lue TF and Guo Y: Clinical applications of low-intensity pulsed ultrasound and its potential role in urology. Transl Androl Urol 5: 255-266, 2016.

11. Czerniak B: Osteosarcoma. In: Bone Tumors. 2nd edition. Elsevier, Philadelphia, pp200-355, 2016.

12. Bandow K, Nishikawa Y, Ohnishi T, Kakimoto K, Soejima K, Iwabuchi S, Kuroe K and Matsuguchi T: Low-intensity pulsed ultrasound (LIPUS) induces RANKL, MCP-1 and MIP-1beta expression in osteoblasts through the angiotensin II type 1 receptor. J Cell Physiol 211: 392-398, 2007.

13. Suzuki A, Takayama T, Suzuki N, Sato M, Fukuda T and Ito K: Daily low-intensity pulsed ultrasound-mediated osteogenic differentiation in rat osteoblasts. Acta Biochim Biophys Sin (Shanghai) 41: 108-115, 2009.

14. Azuma Y, Ito M, Harada Y, Takagi H, Ohta T and Jingushi S: Low-intensity pulsed ultrasound accelerates rat femoral fracture healing by acting on the various cellular reactions in the fracture callus. J Bone Miner Res 16: 671-680, 2001.

15. Naruse K, Miyauchi A, Itoman M and Mikuni-Takagaki Y: Distinct anabolic response of osteoblast to low-intensity pulsed ultrasound. J Bone Miner Res 18: 360-369, 2003.

16. Tang CH, Yang RS, Huang TH, Lu DY, Chuang WJ, Huang TF and Fu WM: Ultrasound stimulates cyclooxygenase-2 expression and increases bone formation through integrin, focal adhesion kinase, phosphatidylinositol 3-kinase, and Akt pathway in osteoblasts. Mol Pharmacol 69: 2047-2057, 2006.

17. Giannoudis PV, MacDonald DA, Matthews SJ, Smith RM, Furlong AJ and De Boer P: Nonunion of the femoral diaphysis. The influence of reaming and non-steroidal anti-inflammatory drugs. J Bone Joint Surg Br 82: 655-658, 2000.

18. Simon AM, Manigrasso MB and O'Connor JP: Cyclo-oxygenase 2 function is essential for bone fracture healing. J Bone Miner Res 17: 963-976, 2002.

19. Feril LB Jr, Kondo T, Cui ZG, Tabuchi Y, Zhao QL, Ando H, Misaki T, Yoshikawa $\mathrm{H}$ and Umemura S: Apoptosis induced by the sonomechanical effects of low intensity pulsed ultrasound in a human leukemia cell line. Cancer Lett 221: 145-152, 2005.

20. Kondo T, Yoshida T, Ogawa R, Hassan MA, Furusawa Y, Zhao QL, Watanabe A, Morii A, Feril LB Jr, Tachibana K, et al: Low-intensity ultrasound adjuvant therapy: Enhancement of doxorubicin-induced cytotoxicity and the acoustic mechanisms involved. J Med Ultrason (2001) 36: 61, 2009.

21. Sawai Y, Murata H, Koto K, Matsui T, Horie N, Ashihara E, Maekawa T, Fushiki S and Kubo T: Effects of low-intensity pulsed ultrasound on osteosarcoma and cancer cells. Oncol Rep 28: 481-486, 2012.

22. Cochran M and Wheatley MA: In vitro gene delivery with ultrasound-triggered polymer microbubbles. Ultrasound Med Biol 39: 1102-1119, 2013. 
23. Shi M, Liu B, Liu G, Wang P, Yang M, Li Y and Zhou J: Low intensity-pulsed ultrasound induced apoptosis of human hepatocellular carcinoma cells in vitro. Ultrasonics 64: 43-53, 2016.

24. Cagnol S and Chambard JC: ERK and cell death: Mechanisms of ERK-induced cell death-apoptosis, autophagy and senescence. FEBS J 277: 2-21, 2010.

25. Duan L, Perez RE, Hansen M, Gitelis S and Maki CG: Increasing cisplatin sensitivity by schedule-dependent inhibition of AKT and Chk1. Cancer Biol Ther 15: 1600-1612, 2014.
26. Waiwut P, Shin MS, Inujima A, Zhou Y, Koizumi K, Saiki I and Sakurai H: Gomisin N enhances TNF- $\alpha$-induced apoptosis via inhibition of the NF-kB and EGFR survival pathways. Mol Cell Biochem 350: 165-175, 2011.

27. Muramatsu Y, Matsui T, Deie M and Sato K: Pulsed electromagnetic field stimulation promotes anti-cell proliferative activity in doxorubicin-treated mouse osteosarcoma cells. In Vivo 31: 61-68, 2017 